\title{
Impact of Quantity and Timeliness of EWOM Information on Consumer's Online Purchase Intention under C2C Environment
}

\author{
Fu Xiaorong, \\ Zhang Bin, \\ Xie Qinghong, \\ Xiao Liuli, \\ Che Yu. \\ Southwestern University of Finance and Economics
}

\begin{abstract}
Based on consumers' "cognitive $\rightarrow$ affective $\rightarrow$ behavior" hierarchy theory of reaction, this paper builds the relational model of electronic word-of-mouth (eWOM) information (from two dimensions, quantity and timeliness), consumer trust, and purchase intention under $\mathrm{C} 2 \mathrm{C}$ environment. The $2 \times 2 \times 2$ between-subjects experiment on 320 undergraduates in Southwestern University of Finance and Economics illustrates that quantity and timeliness of eWOM information have significant influences on consumer trust, which has significantly positive influence on purchase intention; and the effect of the quantity and timeliness of eWOM information on consumer trust is also affected by the difference of product category. When buying fashion product (such as fashionable dress), the influence of quantity and timeliness of eWOM information on consumer trust is greater than that on functional products (such as books).
\end{abstract}

Keywords: C2C, WOM, Consumer trust, Purchase intention

\section{Introduction}

Along with the booming of Internet and e-commerce, more and more people begin to shop on the Internet. Therefore, consumer's online purchase behavior has attracted attention both from the academic circle and the business entities. Literature shows that features of eWOM information have strong influence on online purchase behaviors. Currently, eWOM information has two dimensions, quality and quantity. The quality dimension refers to the features which include path of communication, type, longevity, timeliness, etc (Kozinets, 1999; Park and Lee, 2007; Jin Liyin et. al, 2007). However, researches on timeliness of eWOM information were limited and divergent. Some researchers thought the higher the perceived timeliness of the message is, the greater the usefulness of the message is, and the greater the online purchase intention is (Doll and Torkzadeh, 1988; Madu and Madu, 2002; Cheung et al, 2008). However, Zheng 
Xiaoping's research (2008) found that this information feature has no significant influence on online purchase intention. Why are the research results different from each other? According to some researchers, product type will influence consumer's reliance on online messages and further impact their online purchase behaviors (Nelson, 1970; Senecal, et al, 2004; Bei, 2004; Song, 2005). We have to consider whether the difference in product type is the factor resulting in this difference. And whether the influences of eWOM information quantity and timeliness on consumer trust and purchase intention are different when the consumers purchasing different products?

Therefore, this paper tried to introduce product type as a variable to analyze the integrated influence of product type, quality, and timeliness of eWOM information on consumer's online purchase behaviors. With abundant information about the influence of eWOM information on consumer's online purchase behaviors, this paper hopes to help e-commerce companies to process eWOM information effectively with limited resources, enhance consumer trust, satisfy their individual demands, and win more customers.

\section{Literature Review}

A majority of researches argued that eWOM information has significant influence on online purchase behaviors. Kozinets (1999) stated that eWOM information could effectively decrease consumers' doubts formed from online purchase such as perceived risk, information asymmetry, information absence, etc., so that it can help consumers make purchase decisions. According to Jupiter's research in 1999, eWOM information is an important source for customers to get information about the product because $57 \%$ of customers would look through online consumer reviews (Godes, 2004). Forrester's research (2000) indicated that more than 50\% of young customers would purchase movies, CDs and games according to recommendations from eWOM information. Park and Lee (2007) argued that as a part of eWOM information, online consumer reviews on specific products are valuable information formed from their past experiences. Therefore, the reviews are quite influential and useful for other customers to make purchasing decisions.

\section{The current research of eWOM influence mechanism}

How does eWOM influence consumer buying decision? Smith (2002) investigated the influence of consumers' recommendations on consumer decision-making in virtual community in his doctoral dissertation. In this study, he used three variables (individual difference, features of recommendations and buying target) to describe the influence of eWOM on consumer decisions. He thought that the trust is the mediator variable and target is the moderator variable in this process. His study drew two conclusions: First, trust was the mediator variable which helped to realize the influence of eWOM information on consumer decision; second, the influence of eWOM information on trust varied in different buying environments and for different products.

Smith Menon \& Sivakumar(2005) further discussed the above mentioned results in their following researches. They carried out emulational decision-making experiment to study the influence of WOM on online consumer decision-making. The two empirical studies demonstrated that lots of online consumers would actively look for and accept related information to improve information searching efficiency. This indicated that consumers are always in the state of high involvement. 
Komiak (2003) studied the influence of Recommendation Agents (including features like internalization and familiarity) on consumer adoption intention and decision-making in e-commerce environment. The study argued that internalization and familiarity influence ability-based trust, benevolence-based trust, integrity-based trust and affection-based trust, therefore ultimately influence consumer adoption intention and cognition-assisted preference. On the other hand, ability-based trust, benevolence-based trust, and integrity-based trust bring impact over affect-based trust.

Chen Beilei (2008) divided the factors which influence eWOM communication into three aspects: source, message, and acceptor. Source refers to the expertise, affability and creditability (Rogers, 1995), as well as religion, identity, status, ethics, etc.. Message includes opinions, appeals and conclusions. Acceptor encompasses its ideas, involvement, perusability and characteristics. These contributed to the influencing model of eWOM information on consumer purchasing decision.

$\mathrm{Xu}$ Lin (2007) illustrated the power of eWOM depending on its creditability. This study found five aspects that are strength of relationship between information publisher and reader, the reliance of reader on eWOM communication platform, reader's perceived usefulness of web sites, risks involved and propensity to trust have significant positive impact on eWOM creditability.

Generally speaking, existing researches on eWOM model have drawn two conclusions: First, the influence of eWOM on consumer purchase intention depends on three factors: features of information contributor, features of information and recipients' individual characteristics; second, in the influence mechanism of eWOM on buying intention, trust is the most important mediator variable. That is, the three variables influenced consumer trust first and then on buying intention. At the same time, product type played a moderating role in the process of trust development. Therefore, this paper focuses on the influence mechanism of eWOM information on consumer buying intention.

\section{The current research of eWOM information}

Current studies have analyzed the influence of eWOM information on customer online purchase behaviors. Park and Lee (2009) used experimental study to analyze the influence of direction of eWOM, website reputation and product type on the effect of eWOM communication. The research showed that the influence of negative WOM information is much greater than that of the positive one, the impact of WOM information from websites with reputation is much greater than that from websites without reputation, and product type plays a significant moderating role in the process. The empirical research on eWOM creditability carried out by $\mathrm{Xu}$ Lin (2007) found that the strength of relationship between consumer and information publisher, consumer reliance on eWOM communication platform, their perceived usefulness of websites, risks involved, and propensity to trust have significant positive impact on eWOM creditability. Jin Liyin's research (2007) indicated that type of word-of-mouth information, the direction of communication and the product involvement have significant positive influence on consumer purchase decisions. Furthermore, the interconnection among the three factors also has significant positive impact on the effect of eWOM communication. Zheng Xiaoping (2008) divided online consumer reviews into four types, which are content, creditability, timeliness, 
and quantity. He found that content, creditability and quantity bring significant positive impact over buying decision, but timeliness has no significant influence on buying decision. Xi He's research (2008) illustrated that contributors' expertise, recipients' propensity to trust and perceived risk have significant influence on the effect of eWOM information. However, features of eWOM information and recipients' expertise do not bring any significant impact over the effect of eWOM. Chen Mingliang and Zhang Jingjing's research (2008) on factors which influence eWOM diffusion intention demonstrated that interestingness of content is the most important factor, followed by source creditability, recipients' altruist motivation and the self-promotion motivation. However, the extroversion of recipients' characteristics has no significant influence on eWOM diffusion intention.

The current literature has presented a large amount of analyses about the influence of eWOM information features on online purchase behaviors. However, the current researches have two shortcomings. On one hand, there are limited researches on the interconnection effect of quantity dimension and quality dimension, which are two dimensions of eWOM information. On the other hand, the research on timeliness, the dimension that derives from information quality is also limited and divergent. Therefore, this paper hopes to investigate the influence of quantity and timeliness on consumer trust and purchase intention. Specifically, the quantity of eWOM information refers to the scale and amount of electronic comment on specific product or service. And timeliness of eWOM information means the length of interval between publishing and viewing online.

\section{Consumer trust under $\mathrm{C} 2 \mathrm{C}$ environment}

According to Social Exchange Theory, consumer trust under $\mathrm{C} 2 \mathrm{C}$ environment plays a key role. Social exchange theory is about the rules and regulations controlling resource exchange among people (Frenzen and Nakamoto, 1993). These resources include the economic value of tangible product, the related experience and symbolic value of intangible product or service. Therefore, word-of-mouth is also regarded as a form of social exchange (Gatignon and Robertson, 1986; Frenzen and Nakamoto, 1993). In this exchange, the status of trust will be promoted because of high uncertainties and risks (Molm, Takahasi and Peterson, 2000).

Under $\mathrm{C} 2 \mathrm{C}$ environment, the participants undertake more risk than in the real world. Therefore, we give a new definition of consumer trust under $\mathrm{C} 2 \mathrm{C}$ environment. Corritore and Kracher (2003) thought that "online trust is a kind of attitude, a trustworthy expectation that their vulnerability won't be attacked in online environment." Pavlou (2003) held the view that trusts in e-commerce trade includes the creditability and benevolence of the trustee. Some researchers proposed three dimensions of trust in e-commerce environment, which are the trustee's ability, benevolence, and integrity (Bhattacherjee, 2002; Gefen, 2003). Based on the above mentioned definition, this paper adopts that consumer trust under $\mathrm{C} 2 \mathrm{C}$ environment refers to consumers' perceptions of online sellers' ability, benevolence and integrity, and the consumers' intentions and expectations which are based on the above aspects.

A lot of researchers thought the formation of consumer trust under $\mathrm{C} 2 \mathrm{C}$ environment relies on three aspects, which are the formation of trust on process, feature, and institution (Zucker, 1986). Kim and Prabhakar (2002) demonstrated that consumers' propensity to trust, word-ofmouth and security guarantee are the factors that influence consumer in forming initial trust. Kim et.al $(2005,2008)$ constructed the process-oriented multi-dimensional model of online transaction. This model proposed four classifications that influence consumer trust and their 
perceived risks of e-commerce entity, which includes cognition, emotion, experience and characteristics. This paper researches the influence of eWOM information on cognition-based consumer trust.

Consumer trust is regarded as the most important factor that influences the success of e-commerce transaction (Gefen et al, 2000). Due to uncertainty of seller's behaviors or the perceived risks such as the loss of personal information through hacker attack, consumers often hesitate about the transaction with online sellers (McKnight et al, 2002). Therefore, trust plays a key role in helping consumer overcoming perceived risk and uncertainty. Gefen and Straub (2000) thought that the predictable variable that influences trust is a common phenomenon, and online trust formed in online service is positively related to consumer purchase intention (Cheung and Lee 2006; Gefen and Karahanna 2003; Kim and Steinfield 2008; Pavlou 2003; Pavlou and Gefen 2004; Suh and Han 2003).

\section{Research model and research hypotheses}

Literature review about the influence of eWOM information on purchase intention discovered that consumers will actively look for and evaluate information (Smith Menon \& Sivakumar, 2005). Their decisions are made with high involvement and trust is the most important mediator variable in the process. Therefore, based on consumers' cognitive $\rightarrow$ affective $\rightarrow$ behavior hierarchy theory of reaction, this paper builds the relational model of eWOM information $\rightarrow$ consumer trust $\rightarrow$ purchase intention, and introduces product type as moderator variable to analyze the influence mechanism of eWOM information feature on online purchase behaviors. The model is shown in Figure 1.

Figure 1: The model of eWOM information, consumer trust and purchase intention

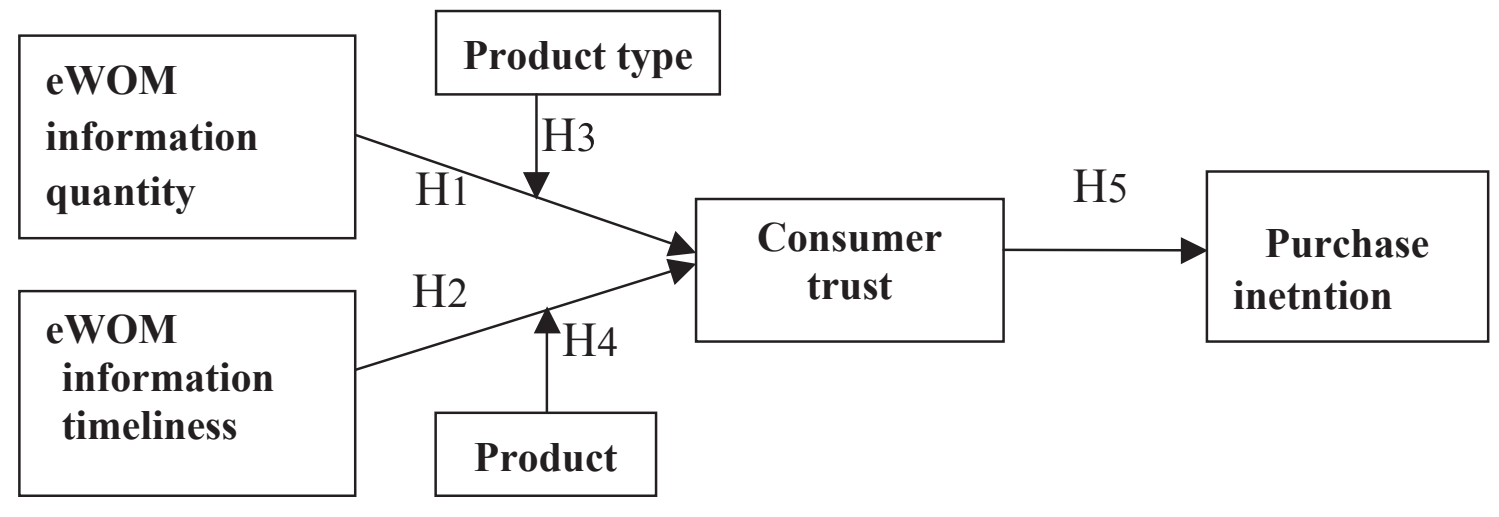

Control variable:

eWOM information direction is positive and of high quanlity

eWOM information is positive valuation eWOM information is of adeauate longevitv

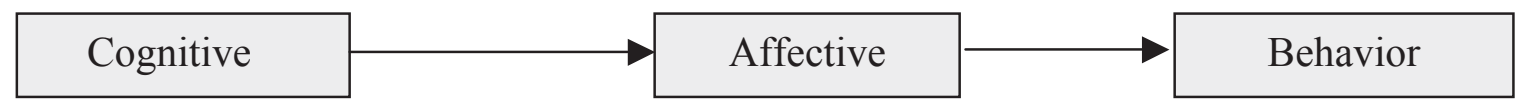




\section{The relationship among eWOM information quantity, timeliness, and trust}

Under C2C environment, people will feel that the majority's behaviors are trustworthy when they are in uncertain context. Chen and Dhanasobhon (2007) carried out specific research on online transaction, pointing out that online evaluation message is helpful for consumer to make buying decision. Consumers would look through messages to evaluate the quality of the product online to eliminate doubts for online shopping and establish trust between buyers and sellers. Ren Chunhua and Liu Yezheng's empirical research (2009) found that eWOM information quantity is positively related to information creditability. Therefore, this research argues

H1: The larger the quantity of eWOM information, the greater the extent of consumer trust.

Doll and Torkzadeh (1988) proposed that in online environment for end-users, eWOM information timeliness is one of the most important factors that influence perceived quality of products. Madu and Madu (2002) urged that when the web site is not updated consistently, the web site cannot deliver the expected performance and therefore provides no added value to users. Cheung et al's research (2008) also proved that the higher the timeliness of message, the higher the creditability perceived by consumers. However, Zheng Xiaoping (2008) found that the influence of timeliness on online purchase behavior is insignificant. This paper holds the view that when consumer purchase product that will lose value rapidly as time goes by, they tend to think that today's reviews are of different value from the reviews (with the same content) left one year ago. Based on the analysis, this research proposes that eWOM information timeliness has significant impact on consumer trust.

$\mathrm{H} 2$ : The higher the timeliness of eWOM information, the greater the extent of consumer trust.

\section{The moderating effect of product type}

Nelson (1970) thought that consumer relies heavily on recommendations when they are buying product whose quality could be confirmed only after the purchasing behavior. It is different from buying product whose quality could be confirmed before purchasing behaviors. Senecal, et al (2004) proved this point through experimental study. Bei et.al's research (2004) revealed that consumer who is buying experiencing products tends to rely heavily on eWOM information, while consumer who is buying searching products will not depend on eWOM information to a great extent because retailer and manufacturer's introductions to searching product are more useful. Song (2005) argued that different product types will produce different influences to consumer. Consumers who buy experiencing product and entertainment product like movies are easier to be influenced by eWOM information. According to literature review, the experiencing product whose quality could be confirmed only after purchasing behavior is called fashion product, while the searching product whose quality could be confirmed in the process of information searching is called functional product. Based on the conclusion, this research argues

H3: The influence of eWOM information quantity on consumer trust when buying fashional product is more significant than that of the functional product.

Zheng Xiaoping (2008) revealed in the empirical study that the influence of eWOM information timeliness on consumer purchase decision is insignificant. Try to consider if the value of today's 
reviews is the same or different when you are buying the fast-depreciating product and the slow-depreciating product. Therefore, this research proposes that due to difference in product type, the influence of eWOM information timeliness on consumer trust varies. Therefore, it is argued that

H4: The influence of eWOM information timeliness on consumer trust when buying fashion product is stronger than that of functional product.

\section{The relationship between trust and online purchase intention}

Azjen and Fishbein's research (1980) found that trust and purchase intention is related. Bowen and Shoemaker (1998) argued that consumers are willing to positively publicize the firms they like and trust then they tend to repurchase the product and service the firms provide. Gefen (2000) stated that consumer trust has direct influence on online purchase intention. Furthermore, Kimery and Mccord (2002) argued that trust established in the process of online shopping helped to decrease consumers' cognition of perceived risks. Trust is positively related to online purchase intention. Koufaris and Hampton-Sosa (2004) and Gefen and Straub (2003) suggested that trust could increase the extent of online users' purchase intention. Liu Weijiang (2005) built a model from the perspective of the features of e-commerce, explaining consumer purchase behaviors in online environment. He thought that trust is the most important ingredient that influences consumer purchasing behavior, and trust is closely related to purchase intention. Donna's empirical research (2006) also demonstrated that trust is positively related to online shopping. Therefore, this paper proposes that

H5: Consumer trust has positive influence on consumer purchase intention.

\section{Method Overview}

The objective of this paper is to demonstrate that the influence of eWOM information quantity and timeliness on consumer purchase intention is different when the customers purchase different products. Therefore, we used a $2 \times 2 \times 2$ between-subjects experimental design: eWOM information quantity (large, small), eWOM information timeliness (high, low), and product type (fashion product, functional product). It is designed to test the differences in consumer trust and purchase intention among these groups.

\section{Method}

At the beginning of the experiment, participants looked through the product reviews in a web page. The product type was either fashion or functional. The information that participants read was different in terms of quantity and timeliness. After finishing reading the information, they expressed the degree of trust and their purchase intention.

\section{Stimuli}

This experiment adopted expert interview method to choose products for experiment. 20 university students with abundant experience in $\mathrm{C} 2 \mathrm{C}$ online shopping participated in the group interview. Based on the interview, we produced a product catalog. After the initial investigation at the aspects of fashion, function, and purchase frequency, we chose the costumes for youth (fashion product) and the books (functional product) as the products for experiment. 
This research used the Delphi investigation method to measure eWOM information quantity and timeliness. The 20 participants explained their understanding of the quantity and timeliness on online messages of fashion clothes and books through email and QQ (a popular communication tool on the Internet in China). The average calculated from the third investigation of 20 participants (the manipulated variable) is as follows:

Table I The measurement of eWOM information quantity and timeliness

\begin{tabular}{|l|l|l|}
\hline \multirow{2}{*}{ Product type } & $\begin{array}{l}\text { The levels of eWOM } \\
\text { information quantity } \\
\text { and timeliness }\end{array}$ & Results \\
\hline \multirow{2}{*}{$\begin{array}{l}\text { Costume } \\
\text { (fashion product) }\end{array}$} & Large quantity & More than 38.5 pieces of messages \\
\cline { 2 - 3 } $\begin{array}{l}\text { Books } \\
\text { (functional } \\
\text { product) }\end{array}$ & Small quantity & Less than 6.1 pieces of messages \\
\cline { 2 - 3 } $\begin{array}{l}\text { Costume } \\
\text { (fashion product) }\end{array}$ & Small quantity & More than 15.6 pieces of messages \\
\hline How timelimes 3 pieces of messages \\
\hline $\begin{array}{l}\text { Books } \\
\text { (functional } \\
\text { product) }\end{array}$ & High timeliness & Messages within 19.65 days \\
\cline { 2 - 3 } & Low timeliness & Messages beyond 58.5 days \\
\hline
\end{tabular}

\section{Procedure}

320 undergraduates in Southwestern University of Finance and Economics participated in the experiment for extra course credit. Participants were randomly assigned to one of eight conditions of a $2 \times 2 \times 2$ between-subjects experimental design: eWOM information quantity (large, small), eWOM information timeliness (high, low), and product type (fashion product, functional product).

We told the participants that the study was aimed at online films and the experimenters who are interested in how people form impressions based on product reviews. Followed by that, all participants read online product reviews. In the small quantity condition, participants had three minutes to read the reviews, while in the large quantity condition, they had six minutes. We also told the participants that in order to get stable measurements of their impressions, they should report their impressions at the same time.

40 undergraduates from the same subject product (the books) evaluated different information quantity along a scale from one to seven. Results confirmed that the online reviews including 16 pieces of massages $(M=4.53)$ were significantly larger than that of 3 pieces of massages $(M=2.03$; $F(1,78)=52.717 ; p<0.001)$. Also, the online reviews published within 48 days $(M=4.85)$ were significantly more timely than that published over 159 days $(M=2.78 ; F(1,78)=36.89 ; p<0.001)$. In customs context, results confirmed that the online reviews including 36 pieces of massage $(M=5.20)$ were significantly larger than that of 6 pieces of massages $(M=2.75 ; F(1,78)=57.132$; $p<0.001)$. Also, the online reviews published within 20 days $(M=5.98)$ were significantly more timely than that published over 59 days $(M=3.73 ; F(1,78)=66.93 ; p<0.001)$. 
After finishing reading these online reviews, the participants finished questions about consumer trust and purchase intention. Consumer trust was measured by three dimensions proposed by Bhattacherjee (2002): ability, integrity, and benevolence. As for purchase intention, we adopted the four-item scale proposed by Jaeki Song et.al (2005).

\section{Results}

\section{Manipulation Checks}

Manipulation check is to assess whether online review's quantity and timeliness are appropriately manipulated. It suggests that the quantity of online reviews perceived by customers is larger when it is presented in large quantity condition $(M=4.77)$ than when it is presented in small quantity condition $(M=2.39 ; F(1,236)=121.553 .6 ; p<0.001)$. Also, as expected, participants think online reviews are more timely when it is presented in high timeliness condition $(M=5.49)$ than when it is presented in low timeliness condition $(M=3.43 ; F(1,236)=102.319 ; p<0.01)$.

\section{Trust Evaluations}

We expected that eWOM information quantity and eWOM information timeliness would affect significantly on customer trust, and product type also affects customer trust by interacting with information quantity and information timeliness. As shown in table 7, this is indeed the case. The $2 \times 2 \times 2$ ANOVA on consumer trust confirmes that the interaction of product type and eWOM information quantity is significant $(F(1,237)=5.258 ; p<0.05)$, and the interaction of product type and eWOM information timeliness is also $\operatorname{significant}(F(1,237)=3.028 ; p<0.1)$.

The results shows the statistics of eWOM quantity $(F=32.14, p<0.01)$ and eWOM timeliness $(F=21.15, p<0.01)$, indicating that the main effect of eWOM quantity and eWOM timeliness is significant at the 0.01 level, and the interaction effect of eWOM quantity and eWOM timeliness on consumer trust is insignificant $(F=0.208, p=0.649>0.05)$. Therefore, $\mathrm{H} 1$ and H2 are approved.

As expected, the results shows that when the two stimuli are highly related, participants' evaluations of trust is significantly different between groups (as shown in figure 3). The means of fashion product (A1) and functional products (F1) to consumer trust are 0.401 and 0.891 respectively, $t=-3.034, p<0.05$, implying that in the conditions of large quantity and high timeliness, product type has significant moderating effect on consumer trust. In the test of A2 and $\mathrm{F} 2, t=-2.637, p<0.05$, indicating that the means of product type to consumer trust are significantly different at the 0.05 level in the condition of small quantity and high timeliness. In the test of A3 and F3, $t=-2.442, p<0.05$, indicating that the means of product type to consumer trust are significantly different at the 0.05 level in the condition of large quantity and low timeliness. In the test of A4 and F4, $t=-0.378, p>0.05$, implying that the means of product type to consumer trust are insignificantly different at the 0.05 level in the condition of small quantity and low timeliness. These statistics demonstrate that consumer trust is low when eWOM information is of small quantity and low timeliness, no matter what kind of product consumer is going to buy online. 
Figure 2: The influence of eight experimental contexts on consumers trust

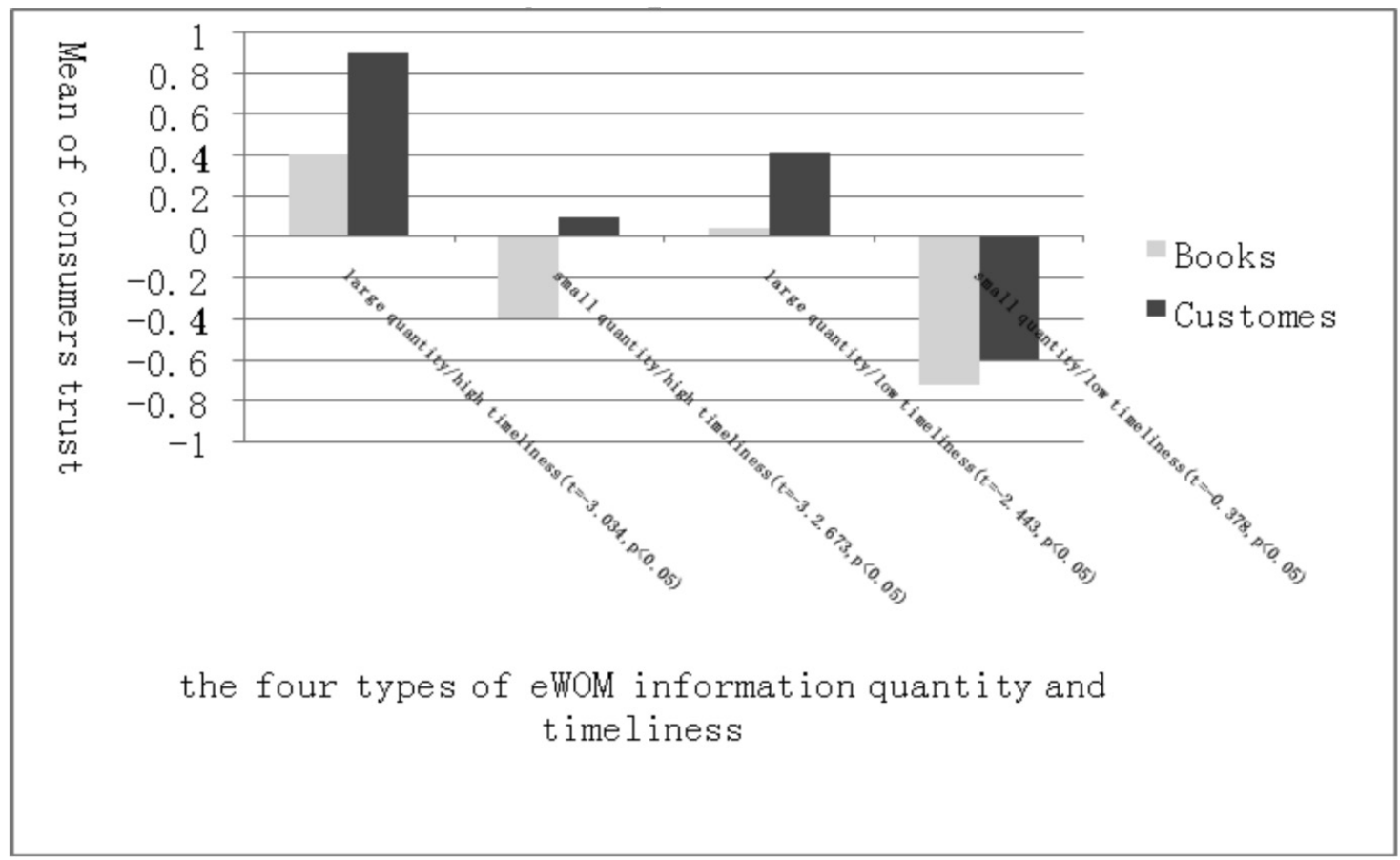

\section{Purchase Intention test}

We adopted regression analysis to test $\mathrm{H} 5$. Based on regression analysis of eWOM information quantity, consumer trust and purchase intention, we prove that the influence of eWOM information quantity on purchase intention is realized through the mediator---consumer trust. Consumer trust displays significant influence on purchase intention. Before the addition of the mediator---consumer trust, the influence of eWOM information quantity on purchase intention was significant $\left(\beta=0.375, p<0.001, R^{2}=0.138\right)$. After the introduction of consumer trust, the influence of eWOM information quantity on purchase intention is insignificant, while consumer trust brings significant influence over purchase intention $\left(\beta=0.863, p<0.001, R^{2}=0.705\right)$.

Furthermore, the model's fitting degree has been improved $(0.705>0.138)$, demonstrating that consumer trust is of good explanation of purchase intention, and consumer trust is a strong mediator between eWOM information quantity and purchase intention. On the other hand, the regression analysis among eWOM information timeliness, consumer trust, and purchase intention also proves that the influence of eWOM information timeliness on purchase intention is realized through the mediator---consumer trust. Consumer trust displayed significant influence to purchase intention. Before the addition of the mediator---consumer trust, the influence of eWOM information timeliness on purchase intention is significant $(\beta=0.272, p<0.001$, $\left.R^{2}=0.071\right)$. After the introduction of consumer trust, the influence of eWOM information timeliness on purchase intention is insignificant, because the consumer trust brings significant influence over purchase intention $\left(\beta=0.822, p<0.001, R^{2}=0.710\right)$. Furthermore, the model's fitting degree has also been improved $(0.710>0.071)$, implying that consumer trust is of good explanation of purchase intention, and consumer trust is a strong mediator between eWOM information timeliness and purchase intention. Therefore, $\mathrm{H} 5$ is accepted. 


\section{Discussion and Conclusion}

The results of experiment confirm our expectation that the impacts of eWOM information quantity and timeliness on customer trust and purchase intention are stronger when buying fashion product. Thus, when participants read the online evaluation messages, they could be affected by their quantity and timeliness. That is to say, the larger the quantity and the higher the timeliness, the greater the extent of consumer trust and purchase intention. Meanwhile, when the consumers make buying decision about fashion product, the influence of eWOM information quantity and timeliness on consumer trust is more significant than that of functional product. The results of experiment have supported our hypotheses.

The experiment in this research proved that under $\mathrm{C} 2 \mathrm{C}$ environment, eWOM quantity and timeliness have significant impact on consumer purchase intention. We have testified the five hypotheses and come to conclusions as follow.

Firstly, the larger the quantity of eWOM information, the greater the extent of consumer trust. In online environment, consumers influence each other. Therefore, the influence on purchase intention would be stronger when a lot of consumers held the same opinion. The conformity effect and the effect of sheep flock have proved this point. In $\mathrm{C} 2 \mathrm{C}$ environment, eWOM information quantity has significant positive influence on consumer trust and consumer trust is significantly positively related to purchase intention. That is to say, the larger the quantity of eWOM information, the greater the extent of consumer trust, and the stronger the consumer purchase intention.

Secondly, the higher the timeliness of eWOM information, the greater the extent of consumer trust. Internet is the main platform to publish information. In the complex network era, C2C firms ought to manage up-to-date messages and delete out-of-date messages. In $\mathrm{C} 2 \mathrm{C}$ environment, eWOM timeliness is significantly positively related to consumer trust and consumer trust is significantly positively related to purchase intention. That is to say, the higher the eWOM timeliness, the greater the extent of consumer trust, and the stronger the purchase intention. This research also finds that the influence of eWOM quantity on consumer trust is bigger than that of eWOM timeliness. When browsing online evaluation messages, consumers firstly focus on quantity and then move to timeliness.

Furthermore, because of the difference in product types, the influences of eWOM quantity and timeliness on consumer trust also differ. When buying different products, consumers' focuses differ from each other because they tend to focus on function or timeliness in different contexts. For example, in buying a classical textbook, online evaluation message is not that important because of low perceived risk. In contrast, online evaluation message plays an important role in buying fashionable cloth because of the uncertainties in design, material, size, and color of the cloth. The experiment results also indicates that influences of eWOM quantity and timeliness on consumer trust and purchase intention in buying fashion product are stronger than these of functional product.

The research conclusion demonstrates that in order to satisfy the consumer's individual needs and boost firm's performance, business firms can strengthen online evaluation message management in the following perspectives: (1) adopt point-based system among consumers who are actively involved in online evaluation activity. The exchange between points and coupons will motivate customers to play a more active part in online evaluation activities, 
so that eWOM information quantity and timeliness could be improved. (2) set up specific online evaluation message management department. Find someone who will be responsible for managing online evaluation message and dealing with customer complaints and suggestions in time, so that customer satisfaction and retention rate could be promoted.

\section{Contributions and Limitations}

Based on the former researches, this paper contributes as follow: (1) based on consumers' "cognitive $\rightarrow$ affective $\rightarrow$ behavior" hierarchy theory of reaction, this paper built the relational model of "eWOM information $\rightarrow$ consumer trust $\rightarrow$ purchase intention" to enrich eWOM information theoretical model; (2) researches in other countries divided product type into two classifications: the searching product and the experiencing product. And found that the influence of eWOM information on consumer purchase behavior differed because of the difference in product type. While in this research, product type was divided into fashion product and functional product due to cultural difference. Furthermore, product type was introduced as moderator variable to analyze the moderating effect of eWOM information on online purchase behavior; (3) this research adopted two dimensions of eWOM information, quantity, and timeliness to analyze their influences on consumer online purchase behavior, which contributed to the related research about the influence of timeliness on consumer online purchasing behaviors.

On the other hand, we concluded the limitations of this research as follows: (1) Focusing on a group of people with abundant online shopping experience, this research didn't confirm the applicability of this model to people without online shopping experience. (2) eWOM information involved in this research were positive messages. However, we didn't prove the influence on consumer trust and purchase intention when there was a proportion of negative online evaluation message (for example, when negative messages account for $20 \%, 50 \%$ or $80 \%$ of the total).

\section{Future research directions}

This research only adopted two dimensions of eWOM information---quantity and timeliness--to analyze their influences on consumer trust and purchase intentions which are based on difference in product type. However, with the development of e-commerce, online evaluation message is becoming complex and diverse, and is calling for further discussion and research. The directions for future research are as follows:

(1) This paper only focuses on analysis of first-time online evaluation message. Some web sites allow second-time evaluation, namely, the subsidiary comment. Therefore the influence of this kind of online evaluation message also calls for further research.

(2) Integrate purchase is becoming popular among online shoppers. The influence of eWOM information on integrate purchase intention needs further discussion, too. Although the operations of various integrate purchase websites seem to be similar to each other, their sales volumes differ significantly. The number of people buying through integrate purchase method could reach 10 or 1000 , and what are the factors resulting in such a big difference? In order to solve the problem, we hope that additional research could be conducted to explore the influencing mechanism of online evaluation message on 
consumers, and put forward suggestions for business firms for products sold through integrate purchase method, so that more customers will be attracted and sales volumes will be promoted.

\section{Reference}

Ajzen, I. \& Fishbein, M. (Eds.). Understanding attitudes and predicting social behavior. New Jersey: Prentice-Hall, 1980.

Ba, S., \& Pavlou, P. A. Evidence of the effect of trust building technology in electronic markets: Price premiums and buyer behavior. MIS Quarterly, 2002, 26(3): 243-268.

Bei, T.L., Chen, I.Y.E., \& Widdows, R. Consumers' online information search behavior and the Phenomenon of search vs. experience Products. Journal of Family and Economic Issues, 2004, 25(4): 449-467.

Bhattaecherjee A. Individual Trust in Online Firms: Scale Development and Initial Test. Journal of Management Information Systems, Summer 2002, Vol. 19: 211-241.

Blackwell, R.D., Miniard, P.W. and Engel, J.F. Consumer Behavior. Orlando: The Dryden Press, 2001.

Bowen, John T. and Stowe Shoemaker, Loyalty: A strategic commitment. Cornell Hotel and Restaurant Administration Quarterly, 1998, 39(1): 12-25.

Burton, S., D.R. Lichtenstein, R.G. Netemeyer, J.A. Garreston. A scale for measuring attitude toward private label products and an examination of its psychological and behavioral correlates. Journal of the Academy of Marketing Science, 1998, 26(4): 293-306.

Cheung, C.M.K., and Lee, M.K.O. Understanding consumer trust in Internet shopping: Amultidisciplinary approach. Journal of the American Society for Information Science and Technology, 2006, 57(4): 479-492.

Christy M.K. Cheung, Matthew K.O. Lee and Neil Rabjohn. The impact of electronic word-of-mouth The adoption of online opinions in online customer communities. Internet Research, Vol. 18, No. 3, 2008: 229-247.

Cynthia, L. Corritore \& Beverly Kracher, Susan Wiedenbeck. Online Trust: Concepts, Evolving Themes, A Model. International Journal of Human computer Studies, 2003: P737, 22p.

D.-H. Park, J. Lee, I. Han. The effects of on-line consumer reviews on consumer purchasing intention: the moderating role of involvement. International Journal of Electronic Commerce, 2007, 11(4): 125-148.

Dodds, William B., Kent B. Monroe, and Dhruv Grewal. The Effects of Price, Brand, and Store Information on Buyers' Product Evaluations. Journal of Marketing Research 1991, 8: 307-319.

Doll, W.J. and Torkzadeh, G. The measurement of end-user computing satisfaction. MIS Quarterly, 1998, Vol.12, No. 2: 259-74.

Doney, P.M, Cannon, J.P. An examination of the nature of trust in buyer-supplier relationships. Journal of Marketing, 1997, 2(April): 35-51. 
Donna Weaver McCloskey. The Importance of Ease of Use, Usefulness, and Trust to Online Consumers : An Examination of the Technology Acceptance Model With Older Consumers. Journal of Organizational and End User Computing, 2006, 18(3).

Fishbein, M., \& Ajzen, I. Belief, Attitude, Intention, and Behavior: An Introduction to Theory and Research. Reading, MA: Addison-Wesley, 1975.

Frenzen, J.K. \& Nakamoto, K. Structure, Cooperation, and the Flow of Market Information. Journal of Consumer Research, 1993, 20(3): 360-375.

Gefen, D. and Straub, D.W. The relative importance of perceived ease of use in IS adoption: a study of e-commerce adoption, Journal of the Association for Information System. 2000, (8): 1-28.

Gatignon, Hubert A. and Thomas S. Robertson. An Exchange Theory Model of Interpersonal Communication. Advances in Consumer Research, 1986, (13): 534-538.

Gefen D, Karahanna E, Straub DW. Trust and TAM in online shopping: An integrated model. Mississippi Quarterly, 2003, 27(1): 51-90.

Gefen D. E-Commerce: The Role of Familiarity and Trust. Omega: The International Journal of Management Science, 2000, 28 (6): 725-737.

Godes D, Mayzlin D. Using online conversations to study word of mouth communication. Marketing Science, 23(4): 545-560.

Grewal, D., K.B. Monroe, R. Krishnan. The effects of price comparisons advertising on buyers perceptions of acquisition value, transaction value, and behavioral intentions. Journal of Marketing, 1998, 62(2): 46-59.

Jaeki Song, Fatemeh Zahedi. Web Design in E-Commerce: A Theory and Empirical Analysis. In Proceedings of ICIS '2001:205-220.

Kim, D.J., Ferrin, D.L., and Rao, H.R. A trust-based consumer decision-making model in electronic commerce: The role of trust, risk, and their antecedents. Decision Support Systems, 2008, 44(2): 554-564.

Kim, D.J., Song, Y.I., Braynov, S.B., and Rao, H.R. A multi-dimensional trust formation model in B-to-C e-commerce: A conceptual framework and content analyses of academia/practitioner perspective. Decision Support Systems, 2005, 40 (2): 143-165.

Kim, D.J., Steinfield, C., and Lai, Y.-J. Revisiting the role of Web assurance seals in business-toconsumer electronic commerce. Decision Support Systems, 2008, 44 (4): 1000-1015.

Kim, K. K., \& Prabhakar, B. Initial trust and the adoption of B2C e-commerce: The case of internet banking. The DATA BASE for advances in Information Systems Research, 2002, 35 (2): 50-64.

Kimery, K.M., \& McCord, M., Third-Party Assurances: Mapping the Road to Trust in E-Retailing. Journal of Information Technology Theory and Application, 2002, 4(2): 64-82.

Komiak S X, Benabast I. Understanding Customer Trust in Agent-Mediated Electronic Commerce, Wed-Mediated Electronic Commerce, and Traditional Commerce. Information Technology and Management, 2004, Jan/Apr, Vol. 5, Issue 1/2: 181-207. 
Koufaris M, William Hampton Sosa. The Development of Initial Trust in an Online Company by New Customers. Information \& Management, 2004,41(3): 377-397.

Kozinets, R. V. E Tribalized Marketing: The Strategic Implications of Virtual Communities of Consumption. European Management Journal, 1999, 17(3): 252-264.

Madu, C.N. and Madu, A.A. Dimensions of e-quality. International Journal of Quality and Reliability Management, 2002, Vol. 19, No. 3: 246-58.

Mayer RC, Davis JH, Schoorman FD. An integrative model of organizational trust. Academy of Management Review, 1995, 20 (3): 709-734.

McAllister, D.J. Affect- and cognition-based trust as foundations for interpersonal cooperation in organizations. Academy of Management Journal, 1995, 38(1): 24-59.

Mcknight D H, Chervany N L. Trust and distrust definitions: one bite at a time. In: Falconer Snghm, Tanyh (eds). Trust in cyber-Societies: Integrating the Human and Artificial Perspectives Berlin: Springer, 2001: 27-54.

McKnight, D. H., Choudhury, V., \& Kacmar, C. Developing and validating trust measures for E-Commerce: An integrative typology. Information Systems Research, 2002, 13(3), 334-359.

Molm, Linda D., Nobuyuki Takahasi and Gretchen Peterson. Risk and Trust in Social Exchange: An Experimental Test of a Classical Proposition. American Journal of Sociology, 105(5): 13961427.

Mullet, Gary M., Karson, Marvin J. Analysis of Purchase Intent Scales Weighted by Probability of Actual Purchase. Journal of Marketing Research, 1985, 22(12): 93-96.

Nelson P J. Information and consumer behavior. Journal of Political Economy, 1970, Vol. 78, Issue 2: p311, 19p.

Park C., Lee T. M. Information direction, website reputation and eWOM effect: A moderating role of product type. Journal of Business Research, 2009, 62 (1): 61- 67.

Park D., Lee J. eWOM overload and its effect on consumer behavioral intention depending on consumer involvement. Electronic Commerce Research and Applications , 2008, 7(4): 386-398.

Pei-yu Chen, Samita Dhanasobhon. Analysis of the Differential Impact of Reviews and Reviewers at Amazon.com. Twenty Eighth International Conference on Information Systems, Montreal 2007.

Pavlou, P.A. Consumer acceptance of electronic commerce: Integrating trust and risk with the technology acceptance model. International Journal of Electronic Commerce, 2003, 7 (3): 101-134.

Pavlou, P.A., and Gefen, D. Building effective online marketplaces with institution-based trust. Information Systems Research, 2004, 15(1): 37-59.

Senecal S., J. Nantel. The influence of online product recommendations on consumers'online choices. Journal of Retailing, 2004, 80: 159-169. 
Smith, D.N. Trust me, would I steer you wrong? The influence of peer recommendations within virtual communities. University of Illinois, Chicago, 2002.

Smith, D., Menon S. and Sivakumar. Online peer and editorial recommendations, trust, and choice in virtual markets. Journal of interactive marketing, 2005, 19(3): 15-37.

Suh, B., and Han, I. The impact of customer trust and perception of security control on the acceptance of electronic commerce. International Journal of Electronic Commerce, 2003, 7(3): 135-161.

Zucker, L. Production of trust: Institutional sources of economic structure (1840-1920). Research in Organizational Behavior, 1986(8): 53-111.

Chen Beilei. An Empirical Analysis of Consumer Online Word-of-Mouth Communication Based on Network and Trust Theory. Zhengjiang University, 2007.5.

Chen Mingliang, and Zhang Jingjing. An Experimental Research on the Determinants of Re-diffusion Intention of Online Word-of-mouth. Journal of Zhejiang University, 2008.9.

JIN Li-yin. The Effects of Online WOM Information on Consumer Purchase Decision: An Experimental Study. Economic Management, 2007.

Liu Weijiang, Liu Yang and Zhang Chaohui. The Trust-Based Purchase model Under E-commerce Environment. Research On Economics and Management, 2005.9.

Sun Chunhua, LIU Yezheng. An Experimental Study on Message Credibility of eWOM. Collected Essays on Finance and Economics. 2009.7.

XI He, XU Jinfa, LUO Shixin and HUANG Guoqun. Comparative Study of the Effect of On-line vs Tranditional WOM on Consumer s Purchase Decision. Finance \& Trade Economics, 2008.2.

XU LIN. An Empirical Analysis of Factors Influencing the Credibility of Online Word-of-Mouth. Finance and Trade Research, 2007.5.

Zhang Ying and SUN Minggui. Review of Online Word-of-Mouth Communication. Finance and Trade Research, 2008.5.

Zheng Xiaoping. An Empirical Study of the Impact of Online Review on Internet Consumer Purchasing Decision. China People's University, 2008.5. 